\title{
Effect of aluminum speciation on arsenic removal during coagulation process
}

\author{
Chengzhi Hu, Huijuan Liu*, Guixia Chen, Jiuhui Qu \\ State Key Laboratory of Environmental Aquatic Chemistry, Research Center for Eco-Environmental Sciences, Chinese Academy of Sciences, Beijing 100085, China
}

\section{A R T I C L E I N F O}

\section{Article history:}

Received 29 August 2011

Received in revised form 9 October 2011

Accepted 10 October 2011

Available online 20 October 2011

\section{Keywords:}

Coagulation

Arsenic

$\mathrm{Al}_{13}$ species

Polyaluminum

\begin{abstract}
A B S T R A C T
The effect of $\mathrm{Al}$ speciation on arsenate $[\mathrm{As}(\mathrm{V})]$ removal during coagulation process was investigated from the viewpoint of $\mathrm{Al}$ hydrolysis species transformation. The $\mathrm{As}(\mathrm{V})$ removal efficiency of preformed $\mathrm{Al}_{13}$ was compared with that of in situ formed $\mathrm{Al}_{13}$ considering various $\mathrm{Al}$ dosages and $\mathrm{pH}$ values. The mechanisms of $\mathrm{As}(\mathrm{V})$ removal by $\mathrm{Al}$ salt coagulation were explored, and adsorption ability of the flocs formed from $\mathrm{Al}_{13}$ species were evaluated. The results showed that $\mathrm{As}(\mathrm{V})$ removal efficiency was positively correlated with the content of $\mathrm{Al}_{13}$ species during coagulation process. Weak acidic condition ( $\mathrm{pH} 5-7$ ) is the optimal $\mathrm{pH}$ range to remove $\mathrm{As}(\mathrm{V})$ because $\mathrm{Al}_{13}$ species, especially for $\mathrm{AlCl}_{3}$, is largely in situ formed from the transformation of monomeric Al species. Through regulating Al speciation, $\mathrm{pH}$ adjustment could improve $\mathrm{As}(\mathrm{V})$ removal and $\mathrm{AlCl}_{3}$ could benefit most from this. In contrast, the improvement induced by $\mathrm{pH}$ control for polyaluminum $(\mathrm{PACl})$ was slighter because $\mathrm{Al}$ speciation of $\mathrm{PACl}$ was less dependent upon water $\mathrm{pH}$. This present study confirmed that adsorption on formed hydroxide flocs was the most active mechanism for $\mathrm{As}(\mathrm{V})$ removal by $\mathrm{Al}$ based coagulants. The flocs generated from in situ formed $\mathrm{Al}_{13}$ presented better $\mathrm{As}(\mathrm{V})$ adsorption ability than the flocs generated from preformed $\mathrm{Al}_{13}$. These findings are important to understand the coagulation mechanisms of arsenic removal by Al based coagulants.
\end{abstract} (c) 2011 Elsevier B.V. All rights reserved.

\section{Introduction}

The removal of arsenic (As) from natural water has been the subject of many studies [1] because drinking water is considered as the main source of exposure to arsenic [2]. Many studies have shown that long-term exposure to As has adverse health effects [2,3], which lead the World Health Organization in 1993 to decrease As standards for drinking water from 50 to $10 \mu \mathrm{g} / \mathrm{L}$. Since July 1, 2007, China's newly revised drinking water standards for the maximum contaminant level (MCL) of As reduced from 50 to $10 \mu \mathrm{g} / \mathrm{L}$. As removal from drinking water is a key measure of endemic arsenism prevention and cure. Drinking water sources in various parts of China and other developing countries contained much higher levels of As $(20-2000 \mu \mathrm{g} / \mathrm{L})$ than MCL requirements [1,4,5].

Enhanced coagulation, is intended to improve natural organic matter (NOM) removal, but is also in many cases the least-cost option for water utilities to comply with the new As MCL [6,7]. Early bench, pilot, and demonstration scale studies have shown that $\mathrm{As}(\mathrm{V})$ can be efficiently removed during coagulation with ferric chloride and alum even when present at low or high concentration in influent waters $[8,9]$. Aluminum $(\mathrm{Al})$ based salts, e.g., polyaluminum chloride $(\mathrm{PACl})$, aluminum chloride $\left(\mathrm{AlCl}_{3}\right)$, and alum (traditional Al coagulants), are most commonly used in water treatment plant. The hydrolysis reactions of Al species are very

\footnotetext{
* Corresponding author. Tel.: +86 106284 9128; fax: +86 1062849160 .

E-mail address: hjliu@rcees.ac.cn (H. Liu).
}

complicated depending on water quality and coagulant type $[10,11]$, which contribute to the formation of various hydrolyzed $\mathrm{Al}$ species. According to the analysis method of Al-ferron complexation timed spectrophotometry or ${ }^{27} \mathrm{Al}$ nuclear magnetic resonance, the $\mathrm{Al}$ species are usually divided into monomeric species (e.g., $\mathrm{Al}(\mathrm{OH})_{2}^{+}, \mathrm{Al}_{2}(\mathrm{OH})_{2}^{4+}, \mathrm{Al}_{3}(\mathrm{OH})_{4}^{5+}$ ), medium polymer species (i.e. $\left.\mathrm{AlO}_{4} \mathrm{Al}_{12}(\mathrm{OH})_{24}\left(\mathrm{H}_{2} \mathrm{O}\right)_{12}^{7+}, \mathrm{Al}_{13}\right)$, colloidal or solid species [1214]. Many researchers [15-17] believed that $\mathrm{PACl}$ was superior to traditional $\mathrm{Al}$ coagulants (i.e. $\mathrm{AlCl}_{3}$ and alum) in removing particulate and $\mathrm{NOM}$ due to the preformed $\mathrm{Al}_{13}$, which has inherent characteristics of high positive charge and strong binding ability [18-20]. Recently, many investigations [21-24] demonstrated the existence of in situ formed $\mathrm{Al}_{13}$ species in $\mathrm{AlCl}_{3}$ at $\mathrm{pH} 5-7$, which made $\mathrm{AlCl}_{3}$ exhibit better removal ability for turbidity and NOM than $\mathrm{PACl}$ at weak acidic $\mathrm{pH}$ conditions.

Al species during coagulation process play a key role in determining the behavior and efficiency of Al based coagulants. Thus, researchers paid more attention to the effect of $\mathrm{Al}$ speciation on coagulation performance. During coagulation, $\mathrm{As}(\mathrm{V})$ is generally removed through two main mechanisms including coprecipitation into growing hydroxide and adsorption on formed hydroxide floc $[25,26]$. Which one is the dominant mechanism depends on the water quality and coagulant dose $[27,28]$. Al hydrolysates in coagulation process varied greatly with the difference of $\mathrm{Al}$ species distribution in coagulant and coagulation $\mathrm{pH}$ condition, which may significantly influence the $\mathrm{As}(\mathrm{V})$ removal performance. Although Al based coagulants have been widely used to meet the standard 
of As MCL in drinking treatment process, the relationship between the different $\mathrm{Al}$ species and $\mathrm{As}(\mathrm{V})$ removal efficiency is still unclear to date. Moreover, few studies focused on the coagulation mechanisms of As removal with $\mathrm{Al}$ based coagulants and the role of $\mathrm{Al}_{13}$ species.

The purpose of this study was to examine the effect of Al species on $\mathrm{As}(\mathrm{V})$ removal during coagulation process. Particular emphasis was placed on understanding the effect of preformed and in situ formed $\mathrm{Al}_{13}$ species on the coagulation performance for $\mathrm{As}(\mathrm{V})$ removal in surface water. The effect of water $\mathrm{pH}$ on $\mathrm{Al}$ speciation and thus on coagulation efficiency was clarified. The present study also provided insight into the mechanism of As removal by $\mathrm{Al}$ based coagulants with different species distribution character.

\section{Materials and methods}

\subsection{Water samples}

Water samples were synthesized by spiking $280 \mu \mathrm{g} / \mathrm{L} \mathrm{As}(\mathrm{V})$ into tap water. Table 1 summarizes the characteristics of the water sample, which simulated natural surface water. Since $A s(V)$ is the prevalent form of arsenic found in surface water, all arsenic removal tests were performed with $\mathrm{As}(\mathrm{V})$. Sodium arsenate $\left(\mathrm{Na}_{2} \mathrm{HA}-\right.$ $\mathrm{sO}_{4} \cdot 7 \mathrm{H}_{2} \mathrm{O}$ ) was used to provide a stock $\mathrm{As}(\mathrm{V})$ solution.

\subsection{Jar test}

Jar tests were performed using a six-paddle stirrer. The procedures consisted of a 2 min rapid mix (200 rpm), 15 min slow mix (40 rpm), and a 30 min settling period. A small amount of sample was taken immediately to measure zeta potential (Malvern, Zetasizer 2000, UK) after $1 \mathrm{~min}$ rapid mix. After settling for $30 \mathrm{~min}$, supernatants were sampled and filtered by $0.45 \mu \mathrm{m}$ pore size membrane filter. The filtrates were tested for $\mathrm{As}(\mathrm{V})$ concentration using spectroscopy equipment (AF-610, Beijing Rull Analytical Instrument Co., Ltd., China) on the basis of hybrid generationatomic fluorescence spectrometry. Finished $\mathrm{pH}$ values were determined with a pH meter (Orion 720A, USA). A pre-determined amount of 0.2 or $0.05 \mathrm{~mol} / \mathrm{L} \mathrm{NaOH}$ or $\mathrm{HCl}$ solution was used to adjust $\mathrm{pH}$ values during rapid mix process. All reagents used are analytical grade chemicals.

\subsection{Characterization of $\mathrm{Al}$ speciation in coagulants}

${ }^{27} \mathrm{Al}$ nuclear magnetic resonance (NMR) spectroscopy was used to characterize the $\mathrm{Al}$ species with ${ }^{27} \mathrm{Al}$ NMR spectra obtained on a VARIANUNITY INOVA $(500 \mathrm{MHz})$ spectrometer. Samples were placed in $5-\mathrm{mm}$ tubes and the spectra were generated at $25^{\circ} \mathrm{C}$. $\mathrm{Al}_{\mathrm{m}}$ (i.e. monomer + dimer), $\mathrm{Al}_{13}$, and $\mathrm{Al}_{\mathrm{u}}$ [i.e. larger polymer species and/or solid phase $\left.\mathrm{Al}(\mathrm{OH})_{3}\right)$ ] can be quantitatively analyzed according to the intensities of ${ }^{27} \mathrm{Al}$ signals. Details of the quantitative analysis of the $\mathrm{Al}$ species can be found in the literature $[12,29]$.

Table 1

Characteristics of water sample.

\begin{tabular}{ll}
$\mathrm{pH}\left(20^{\circ} \mathrm{C}\right)$ & $8.10 \pm 0.05$ \\
Turbidity $(\mathrm{NTU})$ & $0.35 \pm 0.02$ \\
$\mathrm{DOC}(\mathrm{mg} / \mathrm{L})$ & 0.62 \\
Spiked $\mathrm{As}(\mathrm{V})(\mu \mathrm{g} / \mathrm{L})$ & 280 \\
Alkalinity $\left(\mathrm{mg} \mathrm{CaCO}_{3} / \mathrm{L}\right)$ & 150 \\
Hardness $\left(\mathrm{mg} \mathrm{CaCO}_{3} / \mathrm{L}\right)$ & 155 \\
Aluminum $(\mathrm{mg} / \mathrm{L})$ & 0.08 \\
Iron $(\mathrm{mg} / \mathrm{L})$ & 0.05 \\
Total phosphorus $(\mathrm{mg} / \mathrm{L})$ & 0.06 \\
$\mathrm{SO}_{4}^{2-}(\mathrm{mg} / \mathrm{L})$ & 31.7 \\
$\mathrm{Cl}^{-}(\mathrm{mg} / \mathrm{L})$ & 8.9 \\
\hline
\end{tabular}

Ferron colorimetric method was also used to analyze initial Al species distributions of $\mathrm{Al}$ coagulants. The reagents preparation and procedures for the ferron colorimetric method are illustrated in the literature $[10,13]$. Absorbance increase was monitored for 120 min such that three fractions could be operationally defined: $\mathrm{Al}_{\mathrm{a}}, \mathrm{Al}_{\mathrm{b}}$, and $\mathrm{Al}_{\mathrm{c}}$, corresponding to monomeric species, medium polymer species and larger polymer species and/or solid phase $\mathrm{Al}(\mathrm{OH})_{3}$, respectively.

Total Al concentrations $\left(\mathrm{Al}_{\mathrm{T}}\right)$ were determined using ICP-AES (PerakinEimer, Optima 2000, UK). Basicity values (B, OH/Al molar ratios) were determined by titrimetric methods (Standard method of the chemical industry of China).

\subsection{Analysis of Al species distribution during coagulation process}

To study the nature of $\mathrm{Al}$ speciation distributions in the coagulation process, we designed experiments to clarify what happen after dosing coagulants. Synthetic water containing $5 \times 10^{-4} \mathrm{~mol} /$ $\mathrm{L} \mathrm{NaHCO}_{3}$ and $\mathrm{NaNO}_{3}$ in deionized water was prepared. Then, the solution was analyzed subsequently by ferron assay after coagulants was added under rapid stirring at $200 \mathrm{rpm}$ for $2 \mathrm{~min}$. The final solution was $2 \times 10^{-4} \mathrm{~mol} \mathrm{Al} / \mathrm{L}$ and a pre-determined amount of 0.2 or $0.05 \mathrm{~mol} / \mathrm{L} \mathrm{NaOH}$ or $\mathrm{HCl}$ solution was added first into the synthetic water to control $\mathrm{pH}$. Although natural water contains many dissolved chemical species that can affect Al species distributions, deionized water was used for this research to provide baseline species distributions data during coagulation processes, and highlight differences in $\mathrm{Al}$ species distribution among the different coagulants examined.

\subsection{Adsorption experiments}

Adsorption experiments were initiated to evaluate $\mathrm{As}(\mathrm{V})$ removal by adsorption on $\mathrm{Al}$ hydroxide flocs. Al hydroxide flocs were preformed in the tap water by using the jar test method under the same coagulation experimental conditions as during coagulation/ flocculation experiments. Just after the flocculation step, $280 \mu \mathrm{g} / \mathrm{L}$ $\mathrm{As}(\mathrm{V})$ was added to the colloidal suspension and the slow mixing (30 rpm) was maintained for $1 \mathrm{~h}$ to allow arsenic adsorption. After the adsorption step, the settling step was applied. $\mathrm{AlCl}_{3}$ and $\mathrm{PACl}$ were used to form flocs under the same concentrations as during coagulation/flocculation experiments to be able to compare arsenic removal by coagulation and adsorption. Adsorption isotherms experiments were carried out at the same conditions.

\section{Results and discussion}

\subsection{Characterization of Al speciation during coagulation process}

Three coagulants with different $\mathrm{Al}$ speciation distributions were selected to make a comparison on their coagulation behaviors in removing $\mathrm{As}(\mathrm{V}) . \mathrm{AlCl}_{3}(\mathrm{AC})$ was used as traditional Al coagulant. Two PACls (PACl1 and $\mathrm{PACl} 2$ ) were prepared using the electrolysis process [29]. The Al species character of the three coagulants was analyzed by ${ }^{27} \mathrm{Al}$ NMR spectroscopy and ferron colorimetric method. As shown in Table 2, the $\mathrm{Al}_{13}$ contents of the three coagulants followed an increasing order of $\mathrm{AC}<\mathrm{PACl} 1<\mathrm{PACl} 2$, which was in good accordance with that of $B$ value. Many investigations $[13,30]$ proved that the $\mathrm{Al}_{\mathrm{b}}$ species could be regarded as $\mathrm{Al}_{13}$ species. Furthermore, the $\mathrm{Al}_{\mathrm{a}}$ and $\mathrm{Al}_{\mathrm{c}}$ species were approximately equal to the $\mathrm{Al}_{\mathrm{m}}$ and $\mathrm{Al}_{\mathrm{u}}$ species, respectively. From the present study of Al species distribution similar results were obtained. From Table 2, the content of preformed $\mathrm{Al}_{13}$ polymer and $\mathrm{Al}_{\mathrm{b}}$ in $\mathrm{PACl} 2$ reached $73.5 \%$ and $76.9 \%$, respectively. Preformed $\mathrm{Al}_{13}$ polymer 
Table 2

Characterization of coagulants by ${ }^{27} \mathrm{Al}$ NMR and ferron assay.

\begin{tabular}{|c|c|c|c|c|c|c|c|c|c|}
\hline \multirow[t]{2}{*}{ Coagulant } & \multirow[t]{2}{*}{$\mathrm{Al}_{\mathrm{T}}(\mathrm{mol} / \mathrm{L})$} & \multirow[t]{2}{*}{ B } & \multirow[t]{2}{*}{$\mathrm{pH}$} & $\mathrm{Al}_{\mathrm{m}}$ & $\mathrm{Al}_{\mathrm{a}}$ & $\mathrm{Al}_{13}$ & $\mathrm{Al}_{\mathrm{b}}$ & $\mathrm{Al}_{\mathrm{u}}$ & $\mathrm{Al}_{\mathrm{c}}$ \\
\hline & & & & \multicolumn{6}{|l|}{$(\%)$} \\
\hline$A C$ & 0.50 & 0 & 2.38 & 100 & 96.2 & 0 & 3.8 & 0 & 0 \\
\hline PAC1 & 0.58 & 1.15 & 3.50 & 44.8 & 48.7 & 36.3 & 37.9 & 18.9 & 15.4 \\
\hline PAC2 & 0.58 & 2.41 & 4.11 & 8.8 & 10.9 & 73.5 & 76.9 & 17.7 & 12.2 \\
\hline
\end{tabular}

was the predominant species in $\mathrm{PACl} 2$, while there was almost no other species in $\mathrm{AC}$ except $\mathrm{Al}_{\mathrm{m}}$.

The Al speciation distributions of three coagulants during coagulation were studied in the range of $\mathrm{pH} 4-9$. Fig. 1c showed $\mathrm{Al}$ speciation distributions of $\mathrm{PACl} 2$ were relatively stable and tended to maintain the original speciation distributions in coagulation process. The content of preformed $\mathrm{Al}_{\mathrm{b}}$ was almost unchanged throughout the $\mathrm{pH}$ range investigated. In contrast, the results (Fig. 1a) indicated the $\mathrm{Al}$ speciation distributions of $\mathrm{AC}$ during coagulation process changed greatly compared with the initial speciation distributions. In the acidic region, $\mathrm{Al}_{\mathrm{a}}$ decreased rapidly with increase of $\mathrm{pH}$, and reached a minimum in the near neutral $\mathrm{pH}$ region. With increase of $\mathrm{pH}$ to the basic region, the $\mathrm{Al}_{\mathrm{a}}$ species increased sharply again. At the same time, a rapid increase of the $\mathrm{Al}_{\mathrm{b}}$ species was observed in the acidic $\mathrm{pH}$ region. The maximum of $\mathrm{Al}_{\mathrm{b}}$ occurred in the near neutral $\mathrm{pH}$ conditions ( $\mathrm{pH}$ 5.5-7.5). In the basic region, a rapid decrease for $\mathrm{Al}_{\mathrm{b}}$ occurred when $\mathrm{pH}$ was raised. The distribution of $\mathrm{Al}_{\mathrm{c}}$ was similar to that of $\mathrm{Al}_{\mathrm{b}}$, but the scale of change was smaller. Similar trends of the change in $\mathrm{Al}_{\mathrm{a}}, \mathrm{Al}_{\mathrm{b}}$, and $\mathrm{Al}_{\mathrm{c}}$ species was also observable for PACl1 (Fig. 1b), but the scale of change largely decreased.

Obviously, further transformation of $\mathrm{Al}$ species after dosing occurred and depended largely on the original composition of coagulants and water $\mathrm{pH}$. $\mathrm{Al}_{\mathrm{a}}$ fraction in the primary coagulants was the

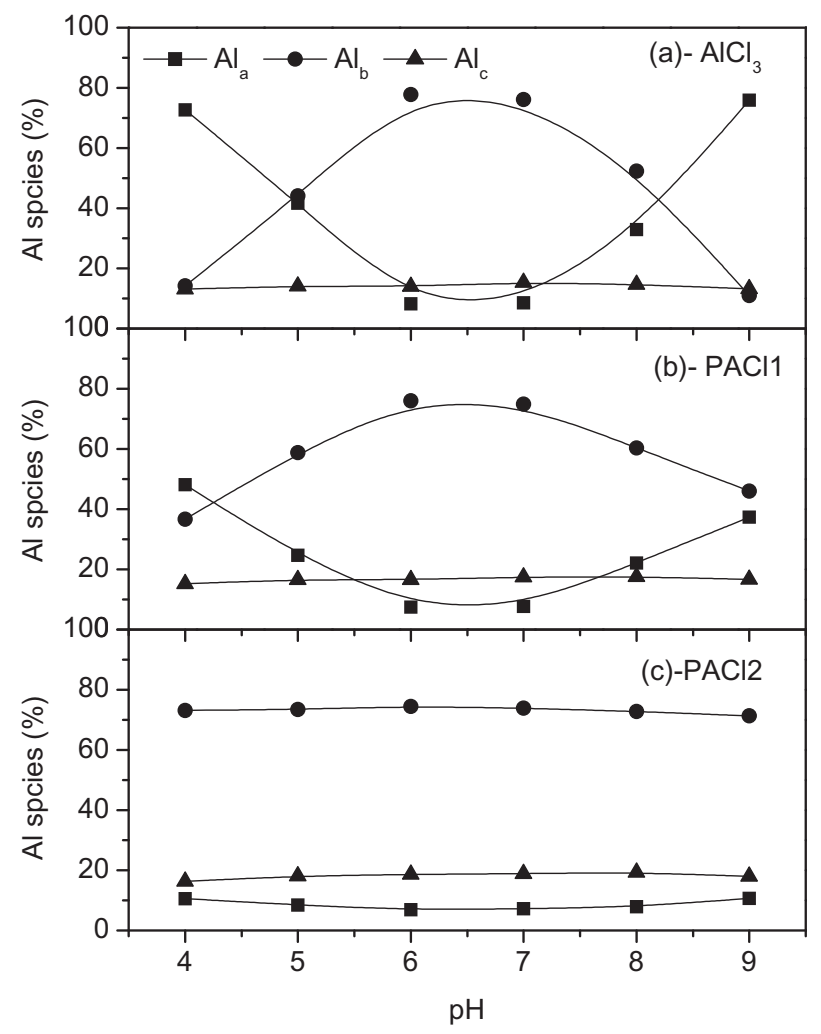

Fig. 1. The speciation characterization after dosing Al coagulants at dosage of $2 \times 10^{-4} \mathrm{~mol} \mathrm{Al} / \mathrm{L}$. most labile species. After dosing, the species would quickly transform into $\mathrm{Al}_{\mathrm{b}}$, and finally $\mathrm{Al}_{\mathrm{c}}$ under appropriate conditions. The polymer species and colloidal species, once preformed, were quite stable. For instance, at $\mathrm{pH} 6$ in $\mathrm{PACl} 2$, the $\mathrm{Al}_{\mathrm{b}}$ fraction still accounted for $74.4 \%$, which was almost equal to the initial content of $\mathrm{Al}_{13}$ (73.5\%). However, at $\mathrm{pH} 6$ in $\mathrm{AlCl}_{3}$, at least $75 \%$ of $\mathrm{Al}_{\mathrm{a}}$ species transformed into $\mathrm{Al}_{\mathrm{b}}$ species, and $15 \%$ further into $\mathrm{Al}_{\mathrm{c}}$. During coagulation process, $\mathrm{Al}_{\mathrm{b}}$ was largely in situ formed under using traditional $\mathrm{Al}$ coagulant while the preformed $\mathrm{Al}_{\mathrm{b}}$ of $\mathrm{PACl}$ was relatively constant, which made their coagulation efficiency different at different $\mathrm{pH}$ conditions.

\subsection{As removal by Al coagulants with different Al species distribution}

As shown in Fig. 2, with the increase of coagulant dosage, As(V) concentration initially decreased, gradually stabilized, then changed to an upward trend. Due to charge neutralization function of coagulants, the surface potential of particles in model water developed from electronegative to electropositive. The $A s(V)$ removal efficiency and zeta potentials increased with the increase of preformed $\mathrm{Al}_{13}$ content in coagulants at low dosages ( 1 to $\sim 4 \mathrm{mg} / \mathrm{L}$ ) and high dosages ( 40 to $\sim 60 \mathrm{mg} / \mathrm{L}$ ). At medium dosages ( 8 to $\sim 32 \mathrm{mg} / \mathrm{L})$, the $\mathrm{As}(\mathrm{V})$ removal efficiency and zeta potentials decreased with the increase of preformed $\mathrm{Al}_{13}$ content in coagulants. All three coagulants had the ability to reduce $\mathrm{As}(\mathrm{V})$ concentration down less than $10 \mu \mathrm{g} / \mathrm{L}$ at initial $\mathrm{As}(\mathrm{V})$ of $280 \mu \mathrm{g} / \mathrm{L}$ in model water, but the required dosages to obtain residual $\mathrm{As}(\mathrm{V})$ of $10 \mu \mathrm{g} / \mathrm{L}$ were different. The minimum dose to satisfy MCL was about $6 \mathrm{mg} / \mathrm{L}$ for AC, however, about $16 \mathrm{mg} / \mathrm{L}$ for $\mathrm{PACl} 2$. As far as the lowest dose to satisfy MCL, the ability of the coagulants for removing As followed the order: $\mathrm{AC}>\mathrm{PACl} 1>\mathrm{PACl} 2$.

Fig. 2 shows that water $\mathrm{pH}$ was depressed by coagulant additions. The dropped ability was inverse to the coagulant basicity. From the lowest dosage to highest dosage, the $\mathrm{pH}$ value decreased from 7.7 to 4.2 with AC addition. It was noted that the finished $\mathrm{pH}$ values with the medium doses of $\mathrm{AC}$ lie in the $\mathrm{pH}$ range of 7 to 5 ,



Fig. 2. The removal of $A s(V)$ and zeta potentials of coagulated material as a function of coagulant dose. 
which was the optimal $\mathrm{pH}$ environment for in situ $\mathrm{Al}_{13}$ formation (Fig. 2). The results showed that the ability of removing $\mathrm{As}(\mathrm{V})$ at the medium dosages was $\mathrm{AC}>\mathrm{PACl} 1>\mathrm{PACl} 2$, and the coagulation efficiency negatively correlated with the preformed $\mathrm{Al}_{13}$ content but positively correlated with the in situ formed $\mathrm{Al}_{13}$ content. At the medium dosages, $\mathrm{AC}$ was more effective than $\mathrm{PACl}$ in removing $\mathrm{As}(\mathrm{V})$ because $\mathrm{AC}$ could function as $\mathrm{pH}$ control agent and then generate $\mathrm{Al}_{13}$ species in the coagulation process. At low and high dosages of $\mathrm{AC}$, the finished $\mathrm{pH}$ values were outside of the weak acidic environment (up pH 7 and below pH 5), where $\mathrm{Al}_{13}$ species could not in situ formed and $\mathrm{Al}_{\mathrm{m}}$ was predominant species during coagulation process for $\mathrm{AC}$. In contrast, preformed $\mathrm{Al}_{13}$ species was independent of $\mathrm{pH}$, thus the dominant species of $\mathrm{PACl} 2$ during coagulation process was still $\mathrm{Al}_{13}$ species under all dosages. Therefore, $\mathrm{PACl}$ performed better for removing $\mathrm{As}(\mathrm{V})$ than $\mathrm{AC}$ at low and high dosages. This phenomenon is consistent with the findings reported by Fan [31]: the As removal efficiencies of PACl were higher than those of its traditional coagulant counterparts at low dosages (0.81-1.89 $\mathrm{mg} \mathrm{Al} / \mathrm{L})$.

It showed that, despite preformed $\mathrm{Al}_{13}$ and in situ formed one, $\mathrm{Al}_{13}$ species was the active species in $\mathrm{Al}$ coagulants responsible for $\mathrm{As}(\mathrm{V})$ removal, which was similar with the results of Al species on removing NOM and particles during coagulation process. Many researchers $[19,20,32]$ claimed that $\mathrm{Al}_{13}$ species had higher charge neutralization ability than $\mathrm{Al}_{\mathrm{m}}$ and $\mathrm{Al}_{\mathrm{c}}$ species, which was also proved by our present research. Fig. 3 showed that zeta potential as a function of coagulant dosages resembled the changing trends of $\mathrm{As}(\mathrm{V})$ removal. The relative $\mathrm{As}(\mathrm{V})$ removal efficiency corresponded well with the charge neutralization ability of the three coagulants. $\mathrm{Al}_{13}$ species, both preformed polymer or in situ formed one, exhibited a stronger charge neutralization ability and thus was more effective on $\mathrm{As}(\mathrm{V})$ removal.

\subsection{Effect of $\mathrm{pH}$ on $\mathrm{As}(\mathrm{V})$ removal by coagulation}

The effect of $\mathrm{pH}$ on $\mathrm{As}(\mathrm{V})$ removal by coagulation and zeta potential of coagulated material was also examined in the range of

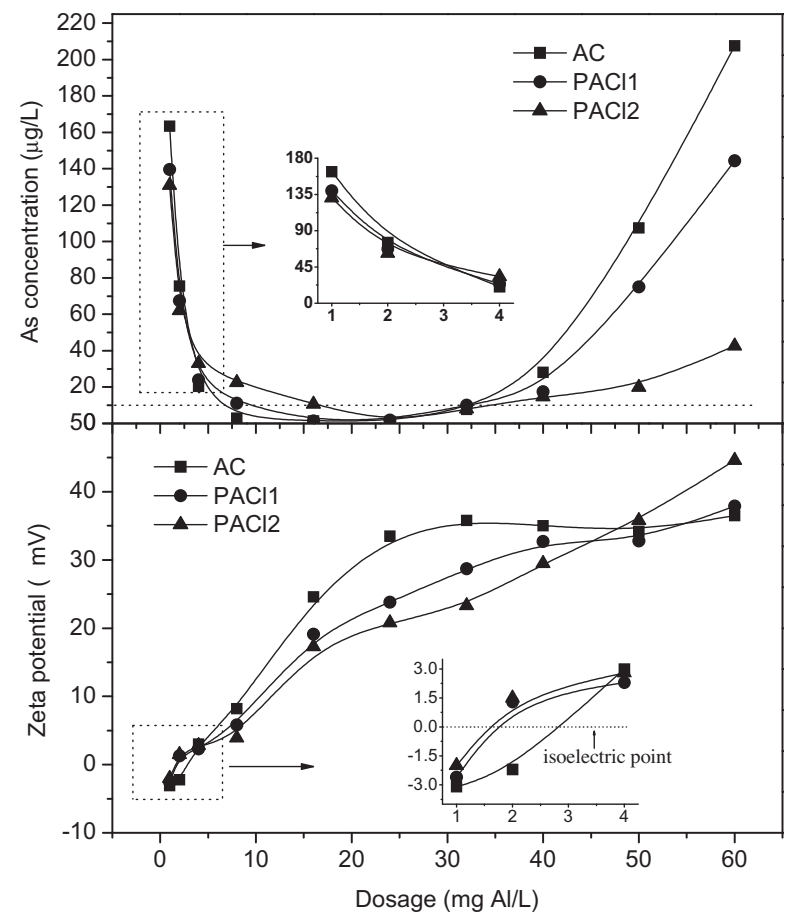

Fig. 3. Finished $\mathrm{pH}$ of water samples as a function of coagulant dose.
pH 4 to $\sim 9$ at two dosages of 2 and $20 \mathrm{mg} / \mathrm{L}$. Fig. 4 showed that the $\mathrm{As}(\mathrm{V})$ removal efficiency and zeta potential of the $20 \mathrm{mg} / \mathrm{L}$ dosage was higher than that of the $2 \mathrm{mg} / \mathrm{L}$ dosage, but the growing trends of their curves were similar. The $\mathrm{As}(\mathrm{V})$ removal efficiency was positively correlated with the zeta potential. It was noted that the $\mathrm{As}(\mathrm{V})$ removal efficiency of AC could be significantly improved by $\mathrm{pH}$ adjustment. The $\mathrm{As}(\mathrm{V})$ removal efficiency of $\mathrm{AC}$ with $2 \mathrm{mg} / \mathrm{L}$ was about 73\% at pH 7.6 (Figs. 2 and 3), while the $\mathrm{As}(\mathrm{V})$ removal efficiency with same dosage could reach $83 \%$ under pH 6 (Fig. 4). The optimal $\mathrm{pH}$ region for removing $\mathrm{As}(\mathrm{V})$ was $\mathrm{pH} 5$ to $\sim 7$. The obtained optimum $\mathrm{pH}$ range for $\mathrm{As}(\mathrm{V})$ removal with $\mathrm{Al}$ based coagulants from this study is in good agreement with the values given in literature $[5,33,34]$.

Comparison of $\mathrm{Al}_{13}$ fraction (Fig. 4a) with effect of $\mathrm{pH}$ on $\mathrm{As}(\mathrm{V})$ removal (Fig. 4c) displayed that $\mathrm{Al}_{13}$ species content in the coagulation process corresponded well to $\mathrm{As}(\mathrm{V})$ removal efficiency at the same $\mathrm{pH}$ values. The $\mathrm{pH}$ region of 5 to $\sim 7$ is not only the optimal $\mathrm{pH}$ range for $\mathrm{As}(\mathrm{V})$ removal but also the optimal $\mathrm{pH}$ environment for in situ $\mathrm{Al}_{13}$ formation. The effect of $\mathrm{pH}$ on the As removal efficiency is related to the $\mathrm{Al}$ species distribution character of $\mathrm{Al}$ based coagulants. The higher ability of removing $\mathrm{As}(\mathrm{V})$ for $\mathrm{AC}$ might come from the higher content of $\mathrm{Al}_{13}$ species than that of $\mathrm{PACl} 2$ at weak acidic $\mathrm{pH}$ range. However, at the acidic and alkaline range (i.e. $\mathrm{pH} 4$ and $\mathrm{pH} 8$ to 9), the ability of removing $\mathrm{As}(\mathrm{V})$ was $\mathrm{PACl} 2>\mathrm{AC}$, where the $\mathrm{As}(\mathrm{V})$ removal efficiency was positively correlated with the preformed $\mathrm{Al}_{13}$ species. Preformed $\mathrm{Al}_{13}$ species was more stable during coagulation process, and could maintain high fraction even in the acidic and alkaline range. With a higher content of preformed $\mathrm{Al}_{13}$ species, $\mathrm{PACl} 2$ was less dependent on $\mathrm{pH}$ to remove $\mathrm{As}(\mathrm{V})$. $\mathrm{pH}$ adjustment could improve $\mathrm{As}(\mathrm{V})$ removal efficiency through regulating $\mathrm{Al}$ species distribution. Especially for traditional Al coagulants, weak acidic condition is the optimal $\mathrm{pH}$ range to remove $\mathrm{As}(\mathrm{V})$ because in situ $\mathrm{Al}_{13}$ is largely formed from the

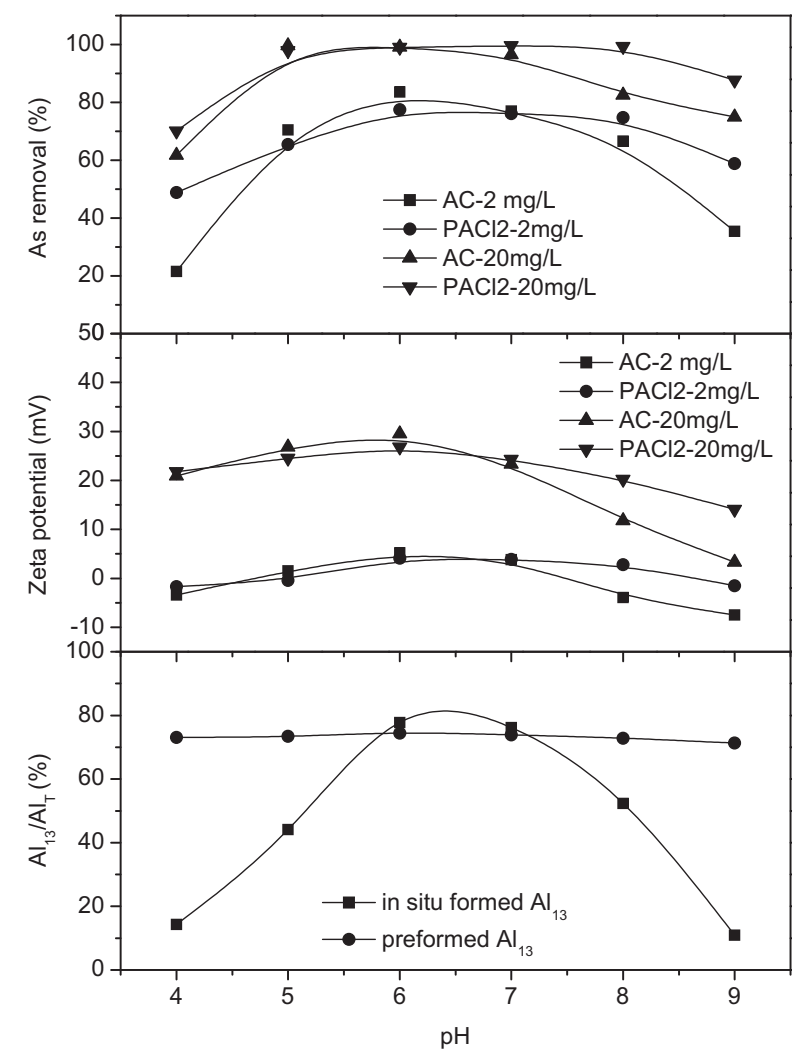

Fig. 4. Effect of $\mathrm{pH}$ on $\mathrm{Al}_{13}$ species distribution, zeta potential of coagulated material, and $\mathrm{As}(\mathrm{V})$ removal efficiency by $\mathrm{Al}$ coagulants. 
transformation of $\mathrm{Al}_{\mathrm{m}}$. However, the improvement induced by $\mathrm{pH}$ control for $\mathrm{PACl}$ was slighter because Al speciation of $\mathrm{PACl}$ was more independent upon water $\mathrm{pH}$.

\subsection{Mechanisms of $A s(V)$ removal by $A$ l based coagulants}

As mentioned above, coprecipitation and adsorption are both active $\mathrm{As}(\mathrm{V})$ removal mechanisms. Special experiments were performed to discriminate which one is predominant and the differences between $\mathrm{AC}$ and $\mathrm{PACl}$ during $\mathrm{As}(\mathrm{V})$ coagulation removal. Adsorption and coagulation data for model water at $\mathrm{pH} 6$ are shown together in Fig. 5. Similar trends were observed in adsorption and coagulation experiments with $\mathrm{AC}$ and $\mathrm{PACl} 2$. Although $\mathrm{As}(\mathrm{V})$ removal by coagulation was more efficient than $\mathrm{As}(\mathrm{V})$ adsorption removal, the differences in $\mathrm{As}(\mathrm{V})$ removal efficiency between adsorption and coagulation were low. Moreover, especially for AC, the differences were more pronounced at low dosages than that at high dosages. The results from these experiments indicate that adsorption onto precipitated $\mathrm{Al}$ hydroxides is the main mechanism for $\mathrm{As}(\mathrm{V})$ removal by $\mathrm{Al}$ coagulants but precipitation/coprecipitation also play specific roles at low dosages. Pallier et al. [28] gained similar results when they studied the behavior of $\mathrm{FeCl}_{3}$ to remove $\mathrm{As}(\mathrm{V})$.

During adsorption on preformed flocs, $\mathrm{As}(\mathrm{V})$ removal depended on the coagulant dose and consequently on the number of active sites on the hydroxide surface $[27,28]$. The more numerous active sites on the hydroxide $\mathrm{Al}$ surface, the higher $\mathrm{As}(\mathrm{V})$ removal efficiency. As shown in Fig. 5, the preformed flocs from AC exhibited better $\mathrm{As}(\mathrm{V})$ adsorption efficiency than the preformed flocs from $\mathrm{PACl} 2$. The different ability of preformed flocs of $\mathrm{AC}$ and $\mathrm{PACl} 2$ in adsorbing $\mathrm{As}(\mathrm{V})$ might be a result of the different flocs structure that was caused by the different $\mathrm{Al}$ species distribution. Xu et al. [24] pointed out the flocs from in situ formed $\mathrm{Al}_{13}$ were larger than that from preformed $\mathrm{Al}_{13}$. Larger flocs may bring an increased collision frequency that lead to adhesion between $\mathrm{Al}$ hydrolysates and $\mathrm{As}(\mathrm{V})$. Beside, owing to the higher positive potential at $\mathrm{pH} 6$ (Fig. 4b), the flocs of AC might give rise to higher adsorption ability than the flocs of $\mathrm{PACl} 2$. This were the reason why a higher $\mathrm{As}(\mathrm{V})$ removal efficiency with $\mathrm{AC}$ flocs was obtained at $\mathrm{pH} 6$ in adsorption experiment.

The adsorption capacity of the preformed flocs from AC and $\mathrm{PACl} 2$ was further investigated. As shown in Fig. 6, the adsorption capacity of AC flocs was significantly higher than $\mathrm{PACl} 2$ flocs. Many researches $[20,23]$ proved the existence of aggregated $\mathrm{Al}_{13}$ in flocs of $\mathrm{PACl}$ and the flocs of $\mathrm{AlCl}_{3}$ at $\mathrm{pH}$, however, which were differ-

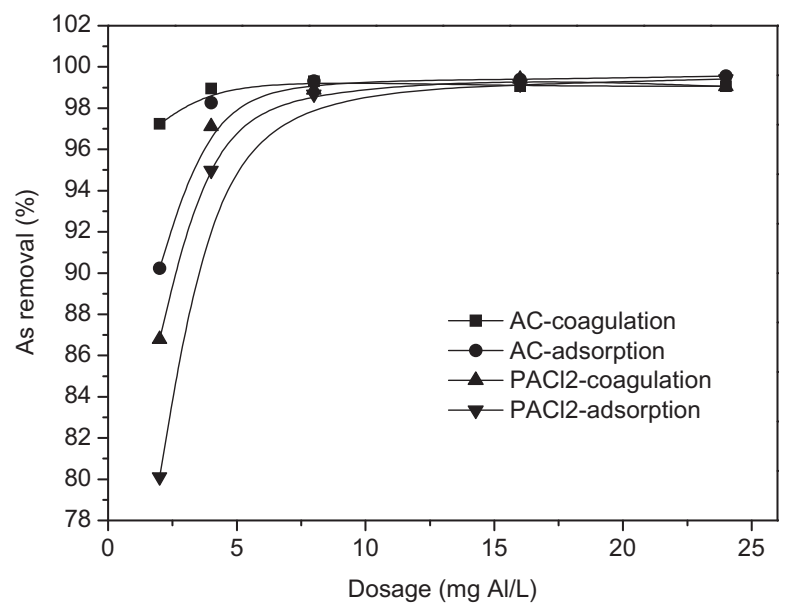

Fig. 5. Comparison of $\mathrm{As}(\mathrm{V})$ removal by coagulation and adsorption on preformed flocs at $\mathrm{pH} 6$.

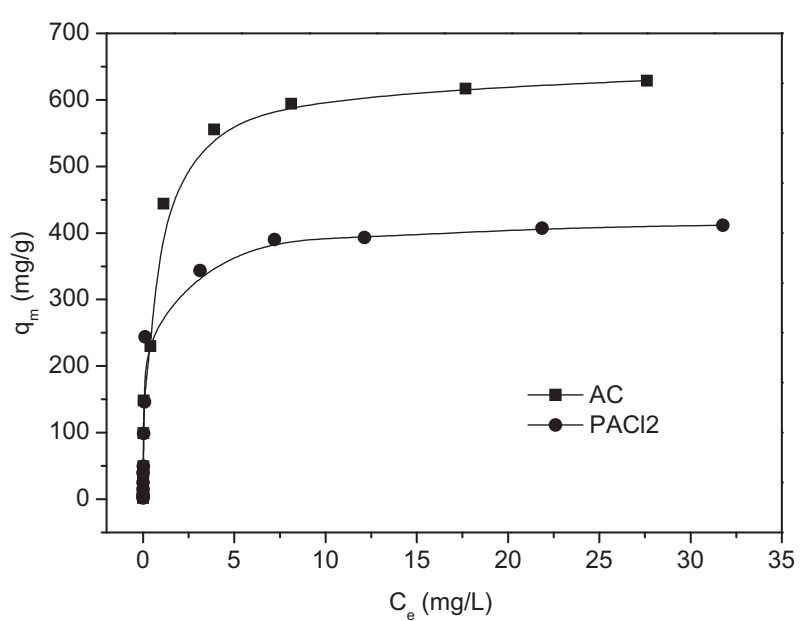

Fig. 6. Adsorption isotherms of $\mathrm{As}(\mathrm{V})$ onto preformed flocs of $\mathrm{AC}$ and $\mathrm{PACl} 2$ at $\mathrm{pH} 6$ (The flocs formed at the dosage of $20 \mathrm{mg} \mathrm{Al} / \mathrm{L}$ ).

ent in crystal type. Previous results $[21,24]$ showed preformed $\mathrm{Al}_{13}$ was quite stable throughout the whole coagulation process even in flocs, but the in situ formed $\mathrm{Al}_{13}$ was not stable and further hydrolyzed into larger polymers, and finally into amorphous hydroxide. Generally, the surface area of amorphous hydroxide is larger than that of crystal hydroxide. Therefore, the flocs of AC could present more adsorption sites than the flocs of $\mathrm{PACl} 2$.

\section{Conclusions}

The results of this paper indicated that, despite preformed $\mathrm{Al}_{13}$ and in situ formed one, $\mathrm{Al}_{13}$ species was the active species in $\mathrm{Al}$ based coagulants responsible for $\mathrm{As}(\mathrm{V})$ removal, and $\mathrm{As}(\mathrm{V})$ removal efficiency was positively correlated with the content of $\mathrm{Al}_{13}$ species during coagulation process. $\mathrm{pH}$ adjustment could improve $\mathrm{As}(\mathrm{V})$ removal efficiency through regulating $\mathrm{Al}$ species distribution. Especially for traditional Al coagulants, weak acidic condition is the optimal $\mathrm{pH}$ range to remove $\mathrm{As}(\mathrm{V})$ because in situ $\mathrm{Al}_{13}$ is largely formed from the transformation of $\mathrm{Al}_{\mathrm{m}}$. In contrast, the improvement induced by $\mathrm{pH}$ control for $\mathrm{PACl}$ was slighter because $\mathrm{Al}$ speciation of $\mathrm{PACl}$ was more independent upon water $\mathrm{pH}$. Present study confirmed that adsorption on formed hydroxide flocs was the most active mechanism of $\mathrm{As}(\mathrm{V})$ removal by $\mathrm{Al}$ based coagulants. With larger surface area, the flocs formed from in situ formed $\mathrm{Al}_{13}$ presented better ability of $\mathrm{As}(\mathrm{V})$ adsorption than the flocs formed from preformed $\mathrm{Al}_{13}$.

\section{Acknowledgments}

The authors are grateful for financial support from the Creative Research Groups of China (No. 50921064), the National High-Tech Research and Development Program (863) of China (No. 2009AA06Z303 and 2009AA06A418), and Major Science and Technology Program for Water Pollution Control and Treatment (2009ZX07424-002-004).

\section{References}

[1] C. Sullivan, M. Tyrer, C.R. Cheeseman, N.J.D. Graham, Disposal of water treatment wastes containing arsenic - a review, Sci. Total Environ. 408 (2010) $1770-1778$.

[2] I. Villaescusa, J.C. Bollinger, Arsenic in drinking water: sources, occurrence, and health effects: a review, Rev. Environ. Sci. Biotechnol. 7 (2008) 307-323.

[3] M.F. Hughes, As toxicity and potential mechanisms of action, Toxicol. Lett. 133 (2002) 1-16.

[4] Y.F. Shen, D.J. Sun, X.H. Zhao, G.Q. Yu, Screening report in areas of endemic arsenism and high content of arsenic in China, Chinese Journal of Endemiology 24 (2005) 172-175. 
[5] B.M. Baskan, A. Pala, A statistical experiment design approach for arsenic removal by coagulation process using aluminum sulfate, Desalination 254 (2010) 42-48.

[6] H.W. Chen, M.M. Frey, D. Clifford, L.S. McNeill, M. Edwards, Arsenic treatment considerations, J. Am. Water Works Assoc. 91 (1999) 74-85.

[7] D. Boccelli, M.J. Small, D. Dzombak, Enhanced coagulation for satisfying the arsenic maximum contaminant level under variable and uncertain conditions, Enviro. Sci. Technol. 39 (2005) 6501-6507.

[8] R.C. Chen, S. Liang, H.C. Wang, M.D. Beyler, Enhanced coagulation for arsenic removal, J. Am. Water Works Ass. 86 (1994) 79-89.

[9] G. Ghurye, D. Clifford, A. Tripp, Iron coagulation and direct microfiltration to remove arsenic from groundwater, J. Am. Water Works Assoc. 96 (2004) 143152.

[10] D.S. Wang, W. Sun, Y. Xu, H.X. Tang, G. John, Speciation stability of inorganic polymer flocculant-PACl, Colloids and Surfaces A: Physicochem. Eng. Aspects 243 (2004) $1-10$

[11] H.Z. Zhao, C. Liu, X. Xu, J.R. Ni, High-concentration polyaluminum chloride: preparation and effects of the $\mathrm{Al}$ concentration on the distribution and transformation of Al species, Chem. Eng. J. 155 (2009) 528-533.

[12] J.W. Akitt, A. Farthing, Aluminum-27 nuclear magnetic resonance studies of the hydrolysis of aluminum (III). Part 5. Slow hydrolysis using aluminum metal, J. Chem. Soc. Dalton Trans. (1981) 1624-1628.

[13] D.R. Parker, P.M. Bertsch, Identification and quantification of the $\mathrm{Al}_{13}$ tridecameric polycation using ferron, Environ. Sci. Technol. 26 (1992) 908-914.

[14] F. Thomas, A. Masion, J.Y. Bottero, J. Rouiller, F. Montigny, F. Genevrier, Aluminum(III) speciation with hydroxy carboxylic-acids-Al-27 NMR study, Environ. Sci. Technol. 27 (1993) 2511-2516.

[15] J.K. Edzwald, Coagulation in drinking water treatment: particles, organics, and coagulants, Water Sci. Technol. 27 (1993) 21-35.

[16] J. Duan, J. Gregory, Coagulation by hydrolyzing metal salts, Advance in Colloid and Interface Science 100-102 (2003) 475-502.

[17] K.A. Gray, C.H. Yao, C.R. O'Melia, Inorganic metal polymers: preparation and characterization, J. Am. Water Works Assoc. 4 (1995) 136-146.

[18] N. Pasrthasarathy, J. Buffle, Study of polymeric aluminum (III) hydroxide solutions for application in waste water treatment: properties of the polymer and optimal conditions preparation, Water Res. 19 (1985) 25-36.

[19] H.Z. Zhao, J.X. Peng, S.S. Lin, Y. Zhang, Covalently bound organic silicate aluminum hybrid coagulants: preparation, characterization, and coagulation behavior, Environ. Sci. Technol. 43 (2009) 2041-2046.
[20] J.L. Lin, C.M. Chin, C.P. Huang, J.R. Pan, D.S. Wang, Coagulation behavior of $\mathrm{Al}_{13}$ aggregates, Water Res. 42 (2008) 4281-4290.

[21] C.Z. Hu, H.J. Liu, J.H. Qu, D.S. Wang, J. Ru, Coagulation behavior of aluminum salts in eutrophic water: significance of $\mathrm{Al}_{13}$ species and $\mathrm{pH}$ control, Environ. Sci. Technol. 40 (2006) 325-331.

[22] M. Yan, D.S. Wang, J.F. Yu, J.R. Ni, M. Edwards, J.H. Qu, Enhanced coagulation with polyaluminum chlorides: role of $\mathrm{pH}$ alkalinity and speciation, Chemosphere 71 (2008) 1665-1673.

[23] H. Zhao, C.Z. Hu, H.J. Liu, X. Zhao, J.H. Qu, Role of aluminum speciation in the removal of disinfection byproduct precursors by a coagulation process, Environ. Sci. Technol. 42 (2008) 5752-5758.

24] W.Y. Xu, B.Y. Gao, Q.Y. Yue, Q Wang, Effect of preformed and non-preformed $\mathrm{Al}_{13}$ species on evolution of floc size, strength, and fractal nature of humic acid flocs in coagulation process, Separ. Sci. Technol. 78 (2011) 83-90.

[25] M. Edwards, Chemistry of arsenic removal during coagulation and Fe-Mn oxidation. J. Am. Water Works Ass. 86 (1994) 79-90.

[26] L.S. McNeill, M. Edwards, Predicting as removal during metal hydroxide precipitation, J. Am. Water Works Ass. 89 (1997) 75-86.

[27] J.G. Hering, P.Y. Chen, J.A. Wilkie, M. Elimelech, Arsenic removal from drinking water during coagulation, J. Environ. Eng.ASCE 123 (1997) 800-807.

[28] V. Pallier, G. Feuillade-Cathalifaud, B. Serpaud, J.C. Bollinger, Effect of organic matter on arsenic removal during coagulation/flocculation treatment, J. Colloid Interf. Sci. 342 (2010) 26-32.

[29] H.J. Liu, J.H. Qu, C.Z. Hu, S.J. Zhang, Characteristics of nanosized polyaluminum chloride coagulant prepared by electrolysis process, Colloids and surfaces A: Physicochem. Eng. Aspects 216 (2003) 139-147.

[30] H.X. Tang, Z.K. Luan, Features and mechanism for coagulation/flocculation processes of polyaluminum chloride, J. Environ. Sci. 7 (1995) 204-211.

31] M.H. Fan, R.C. Brown, S.W. Sung, C.P. Huang, S.K. Ong, J.H. van Leeuwen, Comparisons of polymeric and conventional coagulants in arsenic $(\mathrm{V})$ removal, Water Environ. Res. 75 (2003) 308-313.

[32] J. Buffle, N. Parthasarathy, W. Haerdi, Importance of speciation methods in analytical control of water treatment processes with application to fluoride removal from wastewater, Water Res. 19 (1985) 7-23.

[33] J. Gregor, Arsenic removal during conventional aluminium-based drinking water treatment, Water Res. 35 (2001) 1659-1664.

[34] A. Zouboulis, I. Katsoyiannis, Removal of arsenates from contaminated water by coagulation-direct filtration, Separ. Sci. Technol. 37 (2002) 2859-2873. 